\title{
Determining Academic Success in Students with Disabilities in Higher Education
}

\author{
Stephanie Bain De Los Santos ${ }^{1}$, Lori Kupczynski ${ }^{2} \&$ Marie-Anne Mundy ${ }^{3}$ \\ ${ }^{1}$ Center for Student Success, Texas A\&M University-Kingsville, Kingsville, Texas, USA \\ ${ }^{2}$ College of Health Sciences, University of St. Augustine for Health Sciences, St. Augustine, Florida, USA \\ ${ }^{3}$ College of Education and Human Performance, Texas A\&M University-Kingsville, Kingsville, Texas, USA \\ Correspondence: Lori Kupczynski, College of Health Sciences, University of St. Augustine for Health Sciences, St. \\ Augustine, Florida, USA. E-mail: lkupczynski@usa.edu
}

Received: March 7, 2019

Accepted: March 20, 2019

Online Published: March 21, 2019

doi:10.5430/ijhe.v8n2p16

URL: https://doi.org/10.5430/ijhe.v8n2p16

\begin{abstract}
Students with disabilities have not been fully welcomed in higher education in spite of litigation, court cases, and positive shifts in public perceptions. The transition from high school to college is challenging for students without disabilities. Students with disabilities often get overlooked by their institution and overwhelmed during this transition, contributing to an achievement gap for these students. Student success is measured by retention, academic achievement, and on-time graduation. This research study examined how student success was impacted by a student's registration with the campus disability office, use of accommodations, and use of institutional and social support systems. This study explored a new frontier of research that dispels the myth that students with disabilities are a homogenous group. The results of this study can be used to increase knowledge regarding students with disabilities and their success in higher education. The results will assist college and university administrators as well as staff in disability services offices in tracking the success of accommodations for students with disabilities. This study can help university administration to better understand the benefits of institutional support services as well as encourage faculty involvement in implementing accommodations and helping students see the benefit of student registration with the campus office of disabilities.
\end{abstract}

Keywords: students with disabilities, higher education, support services, office of disabilities, registration

\section{Introduction}

Research shows that as many as $96 \%$ of college and university classrooms have students with disabilities in them. Faculty members, instructors, teaching assistants, and administrators struggle to meet the multitude of needs of an increasingly diverse student body, especially in courses with large enrollments or offered online. Campuses today have increasing populations of students who are not native speakers of English. Students from disadvantaged backgrounds are enrolling as the first in their families to attend college. Older, nontraditional students are entering higher education to obtain undergraduate degrees or returning to campus to earn advanced degrees. In the face of myriad student needs, there is little evidence to show that students with disabilities are receiving the differentiated instruction they need, deserve, and are legally entitled to (McTighe \& Wiggins, 2004).

Students with disabilities are entering higher education at a greater rate than ever before; historically, they do not do as well as their peers without a disability (Sachs \& Schreuer, 2011). Students with disabilities are expected to perform academically perform at the same levels as their non-disabled peers (Couzens, Poed, Kataoka, Brandon, Hartley, \& Keen, 2015). Therefore, it is important for institutions to identify and provide support for them (Kayhan et al., 2015). With graduation completion rates declining across higher education, administrators and teaching staff are pressured more than ever to meet the needs of all students (Kayhan, Sen, \& Akcamete, 2015). In response, institutions of higher education are expanding and reorganizing their support services to meet the needs of students with special needs, including students with disabilities (Couzens et al., 2015).

Dropout rates are exacerbated when students with disabilities feel they are not being supported by their institution (Becker \& Palladino, 2016). Sometimes, this perception is true; other times, this perception is created by invisible barriers. Like all college freshmen, students with disabilities are new to managing adult life, like meals and laundry; they also face the additional challenges of managing their disability without the daily support of parents and teachers. 
Students with disabilities may be reluctant to reach out to their colleges or universities for help or to register for supports and services (Becker \& Palladino, 2016). They may feel embarrassed about having a disability, uncomfortable revealing their disability, may not want to be labeled as someone with a disability, feel ashamed and stigmatized, or lack the knowledge or confidence to discuss their needs (Lechtenberger, Brak, Sokolosky, \& McCrary, 2012; Sachs \& Schreuer, 2011; Blas, 2014). These barriers impact the graduation rates for students with disabilities. The more informed students with disabilities are about their legal rights and the presence of support systems on campus, the more successful they are in higher education (Becker \& Palladino, 2016).

McTighe and Brown (2005) argued that there must be an equilibrium between educational standards for all students and individualized methods to teaching and learning for students with special needs. The simple act of recognizing that learners are diverse is imperative for the academic success of these students (McTighe \& Brown, 2005).

One of the most significant factors affecting the academic success and graduation rates for students with disabilities is the lack of time to focus on school while managing with the effects of a disability or disabilities (Sachs \& Schreuer, 2011). Simply getting around campus may be a challenge. Taking the stairs when an elevator is out is an inconvenience to the typical college student; to the student in a wheelchair, it may make getting to class impossible. Access to adaptive technology, or outdated adaptive technology, may make learning and success harder than it needs to be. Student health services may not be equipped to meet specialized medical needs, requiring assembling a network of off-campus specialists in a new community. While college transfer rates are high for all students, students with disabilities often transfer because they did not or could not receive the proper institutional support in their first institution. Communication and collaboration among faculty, staff, and students contributes immensely to student success (Sachs \& Schreuer, 2011).

Due to the pressure on institutions of higher education to increase rates of retention and on-time graduation, research on how to support student success is multiplying exponentially. This has had a positive effect on research focusing on students with disabilities, which is also being conducted at an accelerated rate (Shallish, 2015). This research study provided quantitative data to determine if student support system usage predicts student academic success. It explored the importance of registering with the campus office of disability and it revealed if academic accommodation use predicts student academic success. Finally, this study added to the existing literature on the impact of institutional and social support systems.

The quantitative design for this study was a non-experimental research study which examined if academic success (GPA) in students with disabilities was affected by a student's registration with the disability office, use of accommodations, use of institutional support systems and interaction with a social support system Participants were recruited using both purposeful and snowball sampling. Surveys from one hundred and twenty-two participants were used. A multiple linear regression analysis was used to determine if academic accommodation use, social support use, institutional support use, and/or registration (independent variables) predicted academic success (dependent variable). SPSS was then used to analyze the data.

\subsection{Statement of the Problem}

Students with disabilities are entering higher education at a greater rate than ever before; historically, they do not do as well as their peers without a disability (Sachs \& Schreuer, 2011). Students with disabilities are expected to academically perform at the same levels as their non-disabled peers (Couzens, Poed, Kataoka, Brandon, Hartley, \& Keen, 2015).

Students with disabilities struggle with low retention rates, increasing the challenges of transferring institutions; longer degree completion times, increasing the financial burden of higher education on these students; and higher dropout rates, limiting career earning potential (Lombardi, Murray \& Gerdes, 2012).

With so many factors affecting their academic performance, students with disabilities often find it difficult to adjust to the expectations and demands of a university. They are not receiving the supports services and accommodations they need to be successful in college (Becker \& Palladino, 2016). Faculty, administrators, and other students may have real or perceived negative attitudes towards them (Lombardi et al., 2012). College students with disabilities who need accommodations must take charge of their own academic careers and seek out disability services (Lechtenberger, Brak, Sokolosky \& McCrary, 2012). The more information that a student has, the more powerful they become to address their needs in education.

It is critical for an institution of higher education to identify the needs of the students with disabilities and provide them with the support they need (Kayhan, Sen \& Akcamete, 2015). However, students with disabilities must self-identify on college and university campuses. By law, higher education faculty, administrators, and support staff cannot seek 
to identify these students. It is a Family Educational Rights and Privacy Act of 1974 (FERPA) violation to ask a student if he or she has a disability. However, because students with disabilities are personally required to take a greater role in advocating for themselves, and perhaps because parents are not there to assist them like they were in high school, many of these students do not register with their campus disability office (Shallish, 2015).

After students enroll at an institution and register with the campus office of disabilities, specific accommodations are determined based on the unique needs of the student. Institutions typically require documentation of an Individualized Education Program or Section 504 plan from the student's secondary institution for the identification of services that have been previously operative for the student (USDoE, 2011). These are used to inform the college accommodation plan.

Although students with disabilities in higher education may have approved accommodations, this does not mean that they have guaranteed access to these approved accommodations (Massengale \& Vasquez, 2016). The institution themselves do not have to make adjustments if they would incur costs that would be a financial or administrative burden (USDoE, 2011). Additionally, students with disabilities must personally coordinate with faculty members to ensure their accommodations. While FERPA allows the campus office of disability to inform faculty of accommodations granted, it is up to the student to pursue this and ensure that accommodations are granted. Failure to do this may mean that an accommodation is not honored because the faculty member was unaware of the student's needs and legal entitlements. The student himself or herself must ensure consistent access to working technology; if a software program malfunctions or a piece of hardware breaks, the student must pursue getting a replacement. If a note-taker or interpreter fails to show up, the student must follow up.

In addition to the need to register with the campus disability office and gain access to recommended accommodations, students with disabilities need support systems Social and institutional support networks help alleviate stress, reduce physical and psychological problems, and lower mortality rates. Stress, specifically, can lead to illness and destructive behaviors such as drug and alcohol consumption, poor diet, and lack of exercise. Types of support systems include emotional, practical, and professional support. By utilizing support systems, students with disabilities have a better chance of achieving academic success (Jairam \& Kahl, 2012)

\subsection{Purpose of the Study}

The purpose of this retrospective, non-experimental research study was to examine how the academic success of students with disabilities were affected by a student's registration with the disability office, use of accommodations, use of institutional support systems and use of social support systems. The results of this study can be used to increase knowledge regarding students with disabilities and their success in higher education. The results will assist college and university administrators as well as staff in disability services offices in tracking the success of accommodations for students with disabilities.

\subsection{Significance of the Study}

This research study provided quantitative data on how student support systems on campus help students with disabilities succeed. It explored the importance of registering with the campus office of disability. It revealed how accommodations impact student academic success.

\subsection{Assumptions}

Several key assumptions pertaining to the overall research design of the current study. First, it was assumed that the participants were students with disabilities. Second, it was assumed that the data given by students were correct, to the best of the participants' knowledge. In other words, students made a good-faith effort to be accurate and honest to further the research objectives. And, finally, it was assumed that the accommodations provided for the students with disabilities were correctly identified and administered in good faith.

\subsection{Limitations of the Study}

Academic success is the outcome of a complex set of interdependent variables. This study focused on a small number of variables that specifically affect students with disabilities. Other variables may have contributed to the success of the students in the current research study, such as the frequency of accommodation use, the level of education and college experiences of their family members, the social and economic resources of their families, and their post-graduation education and career goals. It was not practical to control for these factors given the research design of the current study.

Students who felt successful or who felt marginalized and wanted to have their voice count may have been predisposed to participate. Those who were not finding academic success, or who were overwhelmed with their 
college experience - perhaps the students the researcher most needed to hear from—may have been too stressed to participate.

\subsection{Delimitations of the Study}

The scope of the current research was constrained by funding and other practical variables beyond the control of the researcher. The study was, therefore, delimitated in several ways. First, the study examined the survey responses from students with disabilities. This may impact the generalizability of the research findings. Second, the research took place during the summer and fall semester of 2018. A longer study might have been larger or included more study variables. Finally, participants were students with disabilities who were recruited and who agreed to participate in the study.

\section{Literature Review}

Individuals with disabilities are defined as people with a physical or mental impairment that substantially limits one or more major life activities (USDoE, 2015). Universities today are not prepared for the number of students with disabilities entering their institutions (Gibbons, Cihak, Mynatt \& Wilhoit, 2015).

\subsection{Teaching Students with Disabilities}

Many colleges and universities do not offer the necessary staff trainings or planning processes to effectively accommodate the learning needs of students with disabilities. One of the ways that institutions can prepare faculty and staff to meet the needs of these students is by offering focused professional development. Special education trainings improve faculty attitudes about, knowledge of, and skills to support students with disabilities (Murray, Lombardi, \& Wren, 2011). It is also important to incorporate the university administration and staff in trainings for students with disabilities (Murray et al., 2011). A university's culture of inclusion sets the tone for faculty, staff, and administrative support services for students with disabilities (Murray et al., 2011).

\subsection{Academic Accommodations}

The Americans with Disabilities Act (1990) requires that post-secondary institutions provide reasonable and necessary accommodations when a student discloses a disability. Academic accommodations include alterations to academic tasks like homework, term papers, and examinations; changes to the environment like sitting in front of the classroom or use of adaptive technology; or methods that enable students with disabilities to have an equal opportunity to participate in an academic program, like having an interpreter (USDoE, 2015). Accommodations include adjustments that enable a student with a disability to perform the essential functions of the academic program and to benefit from the academic program in an equitable way compared to their non-disabled peers (USDoE, 2015).

Providing accommodations does not need to take away from the objectives of the curriculum (Becker \& Palladino, 2016). They should not change the academic standards or rigor of a course by lowering or substantially modifying essential requirements. Furthermore, faculty do not have to make adjustments that would result in a financial or administrative burden, such as providing "personal attendants, individually prescribed devices, readers for personal use or study, or other devices or services of a personal nature, such as tutoring and typing" (USDoE, 2015).

Accommodations provide alternative methods to assist students in completing course requirements by removing disability-related barriers (Becker \& Palladino, 2016). Academic accommodations are determined based on the disability and individual needs. They include strategies like:

Arranging for priority registration; reducing a course load; substituting one course for another; providing note takers, recording devices, sign language interpreters, extended time for testing, and, if telephones are provided in dorm rooms, a TTY in a dorm room; and equipping school computers with screen-reading, voice recognition, or other adaptive software or hardware (USDoE, 2011).

\subsection{Accessing Institutional Supports}

Institutions of higher education have the authority to require students to follow reasonable procedures to request academic accommodation. The institution will typically require documentation of an individualized education program (IEP) or Section 504 plan to help identify services that have been effective for the student with disabilities in the past (USDoE, 2015).

\subsection{Faculty Attitudes towards Accommodations}

Although faculty members may not be familiar with ADA compliance, they are still required adhere to the regulations (Becker \& Palladino, 2016). Concerns from faculty members have often arisen due to the vagueness of the accommodation letter given to them by the student. The lack of details in the accommodation letter makes it difficult, if 
not impossible, for the faculty member to effectively modify their lessons for the student (Becker \& Palladino, 2016). Also, faculty often do not know what a reasonable accommodation is and are not educated on techniques to incorporate these in their day-to-day instructional strategies (Becker \& Palladino, 2016).

Faculty willingness to accommodate students with disabilities has also been linked to the type of disability that a student possesses (Becker \& Palladino, 2016). Faculty are more likely to accommodate students with vision and hearing impairments or other physical disabilities than they are to accommodate students with learning and emotional/behavioral disabilities (Becker \& Palladino, 2016). In addition, faculty members can be considered unapproachable or intimidating, leaving the student feeling uncomfortable; therefore, the student may downplay their disabilities and their need for accommodation (Becker \& Palladino, 2016).

\subsection{Student Support Systems}

Couzens et al. (2015) argue that there should be an increased student support system for students with disabilities in higher education. Recent studies show that $9 \%$ of college students identify as having some sort of disability but only $1-3 \%$ of all students register for support services (Lechtenberger et al., 2012).

\subsection{Faculty as a Support System}

Although the number of students with disabilities has increased in the past two decades, many of these students drop out because they feel unsupported, misunderstood, unwelcome, and/or excluded by the institution (Lechtenberger et al., 2012). In fact, students with disabilities have voiced that they do not feel that faculty and administration know how to deal with their needs (Lechtenberger et al., 2012). Faculty members, teaching assistants, and staff are on the front line. They are often the face of the institution for the student. It is the individual faculty member who interacts directly with the students in the classroom and can make the greatest impact on or become a barrier to student success (Becker \& Palladino, 2016). The more awareness faculty and administrators have about students with disabilities, the more likely the student is to stay and the more successful the student can be (Walker, 2016). Becker and Palladino (2016) go so far as to suggest that the non-accommodating, unapproachable faculty member must be removed.

Faculty interaction with students with disabilities can help them learn and give them opportunities to present their knowledge (Becker \& Palladino, 2015). Gibbons et al. (2015) noted that research shows that faculty members who had more contact with students with disabilities had a more positive attitude toward these students, creating a positive feedback loop as well as show that they are then more willing to accommodate and modify teaching in their classrooms (Gibbons et al., 2015). On the other hand, when students feel that faculty members are not aware of or sensitive to their needs, they feel intimidated and rejected (Gibbons et al., 2015). Faculty members may develop a negative attitude toward these students, creating a negative feedback loop.

\subsection{Counseling as a Support System}

The purpose of college counseling services is to assist students whose personal problems affect their well-being and, often, as a result, their academic performance, retention, and graduation (Bishop, 2010). Although studies show that many students place a high value on mental health services, these services are typically underutilized (Eisenburg, Hunt, \& Speer, 2012). Reasons why students do not seek out professional campus counseling services include desire for privacy, fear of being found out, and personal beliefs about the stigma of receiving treatment (Marsh \& Wilcoxon, 2016).

Mental disorders cause more harm among young adults than any other health condition (Eisenburg et al., 2012). A national study found that 4.3 million people did not complete college due to early onset of mental disorders (NAMI, 2012). In addition, a report by the American College Health Association found that $30 \%$ to $45 \%$ of college students in nonclinical campuses reported some form of mental health problem within the last twelve months; fewer than half of these students seek out counseling services (ACHA, 2013). Those students who did seek treatment had often delayed so long that their problem had reached crisis levels (Marsh \& Wilcoxon, 2016).

\subsection{Peer Tutoring as a Support System}

Studying is fundamental for student success in college (Drago, Rheinheimer, \& Detweiler, 2016). More than $40 \%$ of college students do not graduate within six years (NCES, 2014). Causes include procrastination, lack of commitment, and campus distractions (Pugatch \& Wilson, 2018). Additionally, students who procrastinate and cram for exams do not do as well academically as those who have organized study time (Pugatch \& Wilson, 2018).

Students with disabilities continually confront academic challenges (Michael, 2016). To help combat these challenges and improve student success, many colleges and universities offer extensive peer tutoring programs. Recent studies show a positive relationship between peer tutoring and academic performance. 
Peer tutoring is defined as practices and strategies that place student peers as teachers to provide individualized instruction (Drago, Rheinheimer, \& Detweiler, 2016) and allows students to communicate and exchange information (Michael, 2016). In a study done by Arco-Tirado, Fernandez-Martin, \& Fernandez-Balboa (2011), tutoring had a positive effect on grade point average, academic performance, student success, and learning techniques. Types of peer tutoring include small group, individualized, and class-wide (Michael, 2016).

\subsection{Registering with the Campus Disability Office}

There are different requirements to apply for disabilities services in high school and college. School districts must deliver a free appropriate public education (FAPE) to every student with a disability in their district, whereas institutions of higher education are not obligated to deliver FAPE. Institutions of higher education are nevertheless obligated to deliver proper academic support, accommodations, and modifications essential to ensure there is not disability-based discrimination (USDoE, 2015). Though students are not required to notify their college or university of their disability, if they want the school to provide accommodations they must self-identify and register with their school office of disability (Becker \& Palladino, 2016).

In addition, every college and university must have a staff member who organizes and monitors the school's compliance with Section 504 of the Rehabilitation Act of 1973 and/or Title II of the Higher Education Opportunity Act of 2008. Although every campus has a compliance officer, faculty members are not necessarily well-versed in ADA compliance or student accommodations. Faculty members often do not have any interaction with the compliance office to effectively implement the accommodations needed by their students (Becker \& Palladino, 2016). This significantly affects the morale and success of their students with disabilities.

A full $45 \%$ of students who identified as having a disability in high school go on to pursue post-secondary education (Lechtenberger et al., 2012). Although institutions of higher education are required by law to provide information and accommodations for students with disabilities, offices of disability are rarely fully utilized by students to ensure they achieve academic success, graduate on time, and fulfill their highest potential (Lechtenberger et al., 2012). Students with disabilities who are transitioning from high school to college have a difficult time due to the lack of experience managing their own disabilities in high school and a lack of knowledge about campus services for students with disabilities (Lechtenberger et al., 2012).

\section{Methodology}

The purpose of this retrospective, non-experimental research design was to examine how student registration with the disability office, accommodation use, social support use, and institutional support use affected academic success for students with disabilities in higher education. The results of this study increased knowledge regarding students with disabilities and their success in institutions of higher education. The results can assist office of disability services staff in tracking the success of accommodations for college students with disabilities and making the registration process easier. It can help university administration in understanding the benefits of institutional and support services and engage faculty involvement in proactively implementing accommodations for their students with disabilities.

\subsection{Research Questions and Null Hypotheses}

The current research study was directed by the following four research questions:

1. Does registration with the office of disabilities at an institution of higher education predict academic success for students with disabilities?

2. Does academic accommodation use predict academic success for students with disabilities?

3. Does the use of social support predict academic success for students with disabilities?

4. Does the use of institutional support services predict academic success for students with disabilities?

The following null hypotheses were tested:

$\mathrm{H}_{01}$ : There is a not significant relationship between the criterion variable of academic success and the predictor variable of registration with the office of disabilities by students with disabilities.

$\mathrm{H}_{02}$ : There is not a significant relationship between the criterion variable of academic success and the predictor variable of use of academic accommodations.

$\mathrm{H}_{03}$ : There is a significant relationship between the criterion variable of academic success and the predictor variable of use of social support. 
$\mathrm{H}_{04}$ : There is not a significant relationship between the criterion variable of academic success and the use of institutional support systems.

\subsection{Population and Sample}

Students were recruited in two different ways. The first was through purposeful sampling with a four-year, South Texas institution, and the second utilized a snowball effect through the use of social media. The four-year institution has an enrollment of roughly 8,300. The student population come from 35 states and 43 countries. The student body is $53 \%$ percent male and $47 \%$ female. Approximately $62 \%$ of the students at this campus are Hispanic; $27 \%$ are White; $5 \%$ are African American; and 6\% are international students for whom race and ethnicity information was not available. The student to faculty ratio was $16: 1$ and $71 \%$ of the faculty held a doctoral degree. The participants were recruited through email.

The second collection of participants was through Facebook and Twitter. The participants were students with disabilities enrolled in higher education. Students were enrolled part-time or full-time. The study included both men and women over the age of 18. The study included undergraduate students and graduate students. Some students were registered with their campus office of disability and others were not.

\subsection{Participants}

The sample for this study included students with disabilities in higher education. Students were eligible if they identified as a student with a disability. They did not have to be registered with their institution's office of disability. One hundred and eighty-two participants started the survey and 122 completed the survey. Data from completed surveys were used in this analysis.

\subsubsection{Participant Characteristics}

The objective in data collection was to obtain information from students who identified as being a student with a disability in higher education. Table 1 provides the basic demographic information (gender, age, and ethnicity) for these students. As seen in Table 1, a majority of the respondents were female (89.0\%). Participants ranged from 18-62 years of age, with a mean age of 25.7. The higher frequency category was the $20-24$ age category with $50.0 \%$ of the sample indicating they fit into this category with a frequency of 61. Participants who were 19 years of age or less were the next largest category with a frequency of 21 and $17.2 \%$ of the sample population, followed by $25-29$ $(11.5 \%), 35-39(8.2 \%), 30-34(7.4 \%)$, and finally 40 or above $(5.7 \%)$. In regard to ethnicity, the majority of the sample (61.5\%) identified themselves as White/Caucasian, followed by Hispanic (32.0\%), Other (3.3\%), Asian Pacific Islander (2.5\%), and Black or African American (.8\%)

Table 1. Participant Demographics

\begin{tabular}{llr}
\hline Variable & $\mathrm{N}$ & $\%$ \\
\hline Gender & 33 & 27.00 \\
Male & 89 & 73.00 \\
Female & & \\
Age & 21 & 17.20 \\
$18-19$ & 61 & 50.00 \\
$20-24$ & 14 & 11.50 \\
$25-29$ & 9 & 7.40 \\
$30-34$ & 10 & 8.20 \\
$35-39$ & 7 & 5.70 \\
$40+$ & & \\
Ethnicity & 3 & 2.50 \\
Asian Pacific Islander & 1 & .80 \\
Black or African & & \\
American & 39 & 32.00 \\
Hispanic & 75 & 61.50 \\
White/Caucasian & 4 & 3.30 \\
Other &
\end{tabular}


Table 2 highlights the academic characteristics of the sample participants. The largest groups of participants were seniors (28.7\%) and graduate students (25.4\%), with the smallest proportion of respondents being freshmen (9.0\%). Students who identified as full time made up $84.4 \%$ of the sample, and $15.6 \%$ indicated they were part-time students. Participants' grade point averages ranged from .64 to 4.0, with a mean of 2.32, with most students (33.3\%) reporting 3.6 or higher. Finally, $9.0 \%$ were on academic probation at the time of this survey, with $28.7 \%$ having been on academic probation at some point. In addition, $82 \%$ of the sample population had a grade point average (GPA) of 2.6 or better. Areas of studies varied with students indicating majors which included: arts and humanities (33.6\%); business (14.8\%); education (11.5\%); engineering (7.4\%); mathematics (.8\%); sciences $(27.0 \%)$; and technology $(4.9 \%)$.

Table 2. Academic Characteristics of the Sample

\begin{tabular}{lll}
\hline Variable & $\mathrm{N}$ & $\%$ \\
\hline Year in school & & \\
Freshman & 11 & 9.00 \\
Sophomore & 25 & 20.50 \\
Junior & 20 & 16.40 \\
Senior & 35 & 28.70 \\
Graduate Student & 31 & 25.40
\end{tabular}

Major

Arts and Humanities

Business

Education

14

11.50

Engineering

9

7.40

Mathematics

1

Sciences

33

.80

Technology

6

27.00

Student Status

Part-time

19

15.60

Full-time

103

84.40

GPA

Up to 1.5

$1.6-2.0$

$2.1-2.5$

2.6-3.0

3.1-3.5

$3.6-4.0$

On Academic Probation

Yes

No

History of being on Academic Probation

Yes

35

No
$11 \quad 9.0$

$11 \quad 9.0$

111

91.00

2.50

5.70

8.20

21.30

27.90

32.80

$40 \quad 32.80$

91.00

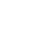

.

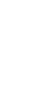

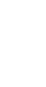




\subsection{Permissions}

Permission was obtained from the Institutional Review Board from the researcher's university to conduct the study (see Appendix A). Permission was given by Howe (2013) to adapt and use her survey questions (see Appendix B).

\subsection{Instrumentation}

A survey instrument was constructed using adapted questions from a previous study (Howe, 2013). Howe's research (2013) provided reliability and validity. There were four main components of the survey: demographic, academic accommodation, social support, and institutional support systems (see Appendix A).

\subsection{Demographics}

Participants were asked to provide information regarding age, gender, ethnicity, year in school, major, disability, and age at onset of disability. In addition, students were asked if they were on academic probation or if they have ever been on academic probation. They were asked if they were attending part-time, attending full-time, or had graduated. Students were also be asked how long they have been receiving academic accommodations as well as their GPA.

\subsection{Academic Accommodations}

Participants were asked to identify if they were currently receiving accommodations. Once they identified, they were asked to state how long they had been receiving them.

\subsection{Use of Social Supports}

Participants were asked to indicate their level of agreement with each of the statements pertaining to the use of social support systems on campus.

\subsection{Use of Institutional Supports}

Participants were asked to indicate their level of agreement with each of the statements pertaining to the use of institutional support on campus.

\subsection{Survey Procedures}

The survey was placed online using Survey Monkey and recruitment took place through email messages, Facebook posts, and Twitter posts. These communications included the hyperlink to the Survey Monkey survey. (See Appendix D). One week after the initial email message, a second email was sent to remind students to take the survey if they had not already done so. Finally, after 2 weeks since the first email/Twitter/or Facebook recruitment email was sent out, the last reminder was sent out. The data was then translated via statistical analysis using the Statistical Package for the Social Sciences (SPSS).

The primary researcher's university email was used recruit the participants from the South Texas University. Facebook posts were used to recruit students (see Appendix D). Messages posted were made on the primary researcher's personal page. Twitter was also used to recruit students (see Appendix D). Messages were tweeted, though the primary researcher's personal account and all were sent out weekly for 3 weeks.

The first page of the survey asked if the student was 18 years or older. The second page shared the informed consent statement that indicated the purpose of the study. Those who answered the initial survey questions and did not meet the criteria for the study were forwarded to a page thanking them for their time and informing them that they did not need to complete the survey.

\subsection{Data Analysis}

This study used four independent variables: academic accommodation use, social support use, institutional support use, and registration with the campus office of disabilities. The study had one dependent variable: academic success for students with disabilities. Demographic information was also collected.

An examination of the descriptive statistics was performed to determine central tendency and variability (Liddicoat \& Taylor-Leech, 2015). The dependent variable was normalized by performing a reflection (Liddicoat \& Taylor-Leech, 2015). Normalization was performed while acknowledging the unique nature of data derived from special populations (McKelvey \& Zavoina,1975). Factor analysis was performed on each item within the independent variables. The correlation matrix and subsequent assumptions testing resulting from the factor analysis led to analysis categories and group totals based on similarity (Spector, 1992). Once groups were identified, a multiple linear regression was conducted as well as Cronbach's alpha to determine reliability (Gleim \& Gleim, 2003). 


\section{Results}

The purpose of this study was to examine academic accommodation use, social support use, institutional support use and registration with the office of disabilities as a predictor of student success. This chapter presents the data preparation and statistical procedures conducted to analyze the data. This chapter also provides descriptive and inferential statistics for the sample and discusses the evaluation of the findings for each research question.

\subsection{Data Preparation}

For the questionnaire data to be imported into excel, several procedures occurred. First, the questionnaire data were downloaded into excel. Next, all incomplete questionnaires were removed as well as those questionnaires responses which did not identify as having a disability that affected their school work. Questions were grouped based on the following categories: demographics, accommodation use, institutional support, social support, and registration. Next, variable columns were labeled without spaces, and all Likert scale items were converted into numerical format $(1,2$, $3,4,5)$. Data were then uploaded to SPSS and the dependent and independent variables were defined in the variable view.

\subsection{Procedures}

Once data were imported into SPSS, an examination of the descriptive statistics was performed to determine central tendency and variability (Liddicoat \& Taylor-Leech, 2015). Table 3 represents the factor analysis findings. The dependent variable was normalized by performing a reflection (Liddicoat \& Taylor-Leech, 2015). Normalization was performed while acknowledging the unique nature of data derived from special populations (McKelvey \& Zavoina,1975). Finally, factor analysis was performed on each item within the independent variables (Thurstone, 1947).

The correlation matrix and subsequent assumptions testing resulting from the factor analysis led to analysis categories and group totals based on similarity (Spector, 1992). Once groups were identified, a multiple linear regression was conducted as well as Cronbach's alpha to determine reliability (Gleim \& Gleim, 2003). The first analysis group identified was academic accommodation. Items identified for the academic accommodation category were:

1. Are you currently receiving academic accommodations?

2. How many semesters have you used academic accommodations?

3. Have you used academic accommodations since your first semester?

4. Indicate you level of agreement: Academic Accommodations have influenced my academic progress. Next, a group of social support questions was created and totaled. Social support items included:

1. I have support within the community.

2. I ask friends for help with school problems.

3. I go to my family members for help with school problems.

4. I have joined or formed study groups with students in my classes.

The third category identified was registration. The registration group questions asked participants to identify if they were registered with the office of disabilities or if they have ever been registered with the office of disabilities.

Factor analysis identified strongly correlated items in institutional support. This resulted in the formation of a fourth research question "Does the use of institutional support predict academic success for students with disabilities?" This category asked participants to indicate their level of agreement with the following statements identified as institutional support systems:

1. Accommodations have been addressed by my professors.

2. Academic needs are being met though accommodations from the disability office.

3. I have sought academic support from the disability office.

4. I go to my professor when I have a problem in class.

5. I go to the disability office for help with school problems.

6. I go to the counseling center for help with problems.

7. I go to my academic adviser for help with school problems.

A fifth category, individual support, was determined during the factor analysis. This category made up one item and therefore was removed. The question determined participants' levels of agreement of the statement: I rely on myself 
to solve my own problems.

Table 3. Factor Analysis

\begin{tabular}{l} 
Variable \\
\hline Registration \\
Currently registered with the Office \\
of Disability
\end{tabular}

Components

Accommodation

Social

Support
Registration

Institutional

Support
Individual

Support

Have you ever been registered with the Office of Disability?

Accommodation

Currently receiving Academic

Accommodations

Semesters used Academic

Accommodations

Have you used academic accommodations since your first semester?

Academic Accommodations have influenced my academic progress

Institutional Support

Accommodations have been addressed by my professors

Academic needs are being met though accommodations from the disability office

I have sought academic support from the disability office

I go to my professor when I have a problem in class

I go to the disability office for help with school problems

I go to the counseling center for help with problems

I go to my academic adviser for help with school problems

\section{Social Support}

I have support within the community .669

I ask friends for help with school problems

I go to my family members for help with school problems

I have joined or formed study groups with students in my classes

I rely on myself to solve my own problems

.672

.831

.632

.784 


\subsection{Descriptive Statistics}

Table 4 highlights frequency, percentage, and standard deviation for the registration, accommodation, institutional support, and social support components of the questionnaire. In the registration portion of the questionnaire, the majority of students were registered with the office of disability (54.9\%) and have been registered with the office of disability previously $(48.4 \%)$. In the accommodation portion of the questionnaire, the majority of the participants $(63.1 \%)$ were not receiving academic accommodations with the number of semesters using academic accommodations varied from 0 to 24 semesters. Only $18 \%$ of the participants answered that they had used academic accommodations since their first semester and 38.5\% answered that accommodations influenced their academic progress.

In the institutional portion of the questionnaire, professors are addressing less than half (46.7\%) of the participants' accommodation needs while the majority (77.7\%) said they went to their professors for help with problems in class. Forty-one-point eight percent of the participants have sought academic support from the office of disabilities at some point in their college career while only $30.4 \%$ agreed that their academic accommodation needs are being met through the disability office and the smallest percentage (22.2\%) of participants go to them for help with academic problems. Only a third of the participants (33.6\%) utilized the counseling center as a place to go for help with their problems and less than half of the participants (41\%) go to their academic advisor for help with their school problems.

The social support component of the questionnaire revealed that the majority of participants relied on themselves to solve their own problems $(81.9 \%)$, followed by going to their friends $(70.5 \%)$ for help with their school problems, followed by their family $(57.4 \%)$ study groups $(57.4 \%)$, and finally their community (43.6\%).

Table 4. Descriptive Statistics for Questionnaires

\begin{tabular}{lllll}
\hline Variable & Frequency & $\begin{array}{l}\text { Percentage } \\
(\%)\end{array}$ & Mean & $\begin{array}{l}\text { Standard } \\
\text { Deviation (SD) }\end{array}$ \\
\hline
\end{tabular}

Registration

Currently registered with the Office of Disability

No

Yes

Have you ever been registered with the Office of Disability?

No

Yes

Currently receiving Academic Accommodations

No

Yes

Semesters used Academic Accommodations

Have you used academic accommodations since your first semester?

No

Academic Accommodations have influenced my academic progress

Agree

Disagree

Institutional Support

Accommodations have been addressed by my professors
$.45 \quad .500$

54.9

45.1

$55 \quad 45.1$

63

51.6

59

48.4

77

63.1

45

36.9

Varied

Varied

$2.40 \quad 3.964$

$.30 \quad .458$

18

29.5

36

$2.81 \quad 1.138$

38.5

$27 \quad 22.2$

$.48 \quad .520$

$.37 \quad .484$

3.964
.458

1.138 


\section{Agree}

Disagree

Academic needs are being met though accommodations from the disability office

\section{Agree}

Disagree

I have sought academic support from the disability office

\section{Agree}

Disagree

I go to my professor when I have a problem in class

Agree

Disagree

I go to the disability office for help with school problems

Agree

Disagree

I go to the counseling center for help with problems

$$
\text { Agree }
$$

Disagree

I go to my academic adviser for help with school problems

Agree

Social Support

I have support within the community

$$
\text { Agree }
$$

Disagree

I ask friends for help with school problems

Agree

Disagree

I go to my family members for help with school problems

Agree

Disagree

I have joined or formed study groups with students in my classes

Agree

Disagree

I rely on myself to solve my own problems

Agree

Disagree

\section{7}

17

37

42

1.379

51

51

95

13

27

62

41

52

50

44

41

36.1

30.4

35.3

41.8

41.8

$2.03 \quad .944$

77.8

10.6

22.2

50.8

$3.18 \quad 1.324$

33.6

42.6

$3.02 \quad 1.171$
$3.16 \quad 1.195$

$2.91 \quad 1.206$

43.6

27.9

$2.34 \quad 1.225$

70.5

20.5

$2.65 \quad 1.354$

57.4

28.7

$2.65 \quad 1.311$

57.4

27

35

100

$1.84 \quad .939$

81.9

$\begin{array}{ll}7 & 5.8\end{array}$




\subsection{Inferential Statistics}

\subsubsection{Multiple Regression Analysis}

A multiple regression analysis was conducted to determine the best linear combination of registration, social support, institutional support and/or academic accommodation usage for predicting student success as measured by GPA (assumption of linearity normally distributed errors, and uncorrelated errors were checked). The means, standard deviations, and intercorrelations can be found in in table 7 . This combination of variables did not predict GPA, F(4, $117)=.90, p=.47$, with none of the four variables being significant. The adjusted $R^{2}$, as represented in table 6 was -.003 with $\mathrm{R}^{2}$ being .03 . This indicates that $.3 \%$ of the variance in GPA was explained by the model. According to Cohen (1988), this is a negligible effect. The null hypothesis failed to be rejected in each and every case.

Table 5. Multiple Regression Results

\begin{tabular}{lllll}
\hline Variable & \multicolumn{2}{l}{ Unstandardized Coefficients } & $t$ & Sig. $(p)$ \\
& Beta (B) & Standard Error & & .231 \\
\hline Accommodation Use & .018 & .015 & 1.204 & .560 \\
Registration & .020 & .035 & -1.233 & .577 \\
Social Supports & -.022 & .018 & .053 & .958 \\
Institutional Support & .001 & .028 & & .220 \\
\hline
\end{tabular}

Table 6. Model Summary

\begin{tabular}{|c|c|c|c|c|}
\hline Model & $\mathrm{R}$ & R Squared & Adjusted R Squared & $\begin{array}{l}\text { Standard Error of } \\
\text { the Estimate }\end{array}$ \\
\hline 1 & .173 & .030 & -.003 & .65024 \\
\hline
\end{tabular}

Table 7. Means and Standard Deviations

\begin{tabular}{lll}
\hline Variable & Mean & Standard Deviation \\
\hline Accommodation Use & 6.23 & -4.16 \\
Registration & 7.51 & 1.87 \\
Social Supports & 10.55 & 3.46 \\
Institutional Support & 8.23 & 2.40 \\
\hline
\end{tabular}

\subsection{Evaluation of Findings}

The findings of this research were both supported and rejected by previous research and the literature. The null hypothesis was not rejected as none of the variables predicted academic success (GPA). This is not consistent with previous research in which at least one of the independent variables (registration, institutional support, accommodation use, or social support) predicted academic success (Howe, 2013).

Findings which supported previous research included that there is a lack of student registration with the office of disability on their respective campuses (Couzens et al., 2015). Specifically, 54.9\% of the participants were currently registered with the office of disabilities with $48.4 \%$ of them registering previously. In addition, $63.1 \%$ of the participants were not receiving academic accommodations while only $18 \%$ of them answered they had used academic accommodations since their first semester and 38.5\% answered accommodations influenced their academic progress. Previous research shows that students with academic accommodations have a better chance of achieving academic success in higher education. Therefore, the findings of this study are not consistent with previous research (Couzens et al., 2015).

Other findings included professors addressing less than half (46.7\%) of the participants' accommodation needs while recent research shows that many faculty are uncertain as to the expectations for accommodations (Gibbons et al., 
2015). In addition, most of the participants went to their faculty members for help with problems in the class (77.7\%). This does not support other research on institutional support which states that faculty members can be considered unapproachable or intimidating and therefore students do not go to them for help (Becker \& Palladino, 2016). Other results included, $41.8 \%$ of the participants having sought academic support from the office of disabilities at some point of their college career while only $30.4 \%$ agree that their academic accommodation needs are being met through the disability office and the smallest percentage (22.2\%) of them go to the office of disabilities for help with their school problems. To support this, studies show that students are not utilizing the office of disability on their campuses (Lechtenberger et al., 2012). Also, only a third of the participants utilized the counseling center (33.6\%) as a place to go for help with their problems and less than half of the participants (41\%) go to their academic advisor with their school problems. Studies show that although students value counseling services, they are typically underutilized (Eisenburg, Hunt, \& Speer, 2012).

\subsection{Summary}

Descriptive data provided on participant demographics and academic characteristics were also provided. An examination of the descriptive statistics was performed to determine central tendency and variability (Liddicoat \& Taylor-Leech, 2015). The dependent variable was normalized by performing a reflection (Liddicoat \& Taylor-Leech, 2015). Normalization was performed while acknowledging the unique nature of data derived from special populations (McKelvey \& Zavoina, 1975). Factor analysis was performed on each item within the independent variables. The correlation matrix and subsequent assumptions testing resulting from the factor analysis led to analysis categories and group totals based on similarity (Spector, 1992). Once groups were identified, a multiple linear regression was conducted as well as Cronbach's alpha to determine reliability (Gleim \& Gleim, 2003).

\section{Discussion}

This study examined how the academic success (GPA) of students with disabilities was affected by a student's registration with the disability office, use of accommodations, and use of institutional support and social support systems. Participants were recruited using both purposeful and snowball sampling. Surveys from one hundred and twenty-two participants were used. A multiple linear regression analysis was used to determine if academic accommodation use, social support use, institutional support use, and/or registration (independent variables) predicted academic success (dependent variable). SPSS was then used to analyze the data. The findings resulted in none of the variables significantly predicting academic success as measured by GPA.

\subsection{Conclusions}

The results of this story are both consistent and inconsistent with previous research on this subject (Howe, 2013). Furthermore, the null hypothesis was not rejected as none of the variables predicted academic success (GPA). This is not consistent with previous research in which at least one of the independent variables (registration, institutional support, accommodation use, or social support) predicted academic success (Howe, 2013).

RQ1 Does registration with the office of disabilities at an institution of higher education predict academic success for students with disabilities?

In predicting academic success, the null hypothesis was not rejected as registration with the office of disabilities did not predict GPA. This finding is consistent with the literature in reference to overall registration as previous research found that there is a lack of student registration with the office of disabilities on their campuses (Couzens et al., 2015). Recent studies show that $9 \%$ of college students identify as having some sort of disability but only 1-3\% of all students register for support services (Lechtenberger et al., 2012).

However, because students with disabilities are personally required to take a greater role in advocating for themselves, and perhaps because parents are not there to assist them like they were in high school, many of these students do not register with their campus disability office (Shallish, 2015). Specifically, 54.9\% of the participants were currently registered with the office of disabilities with $48.4 \%$ of them registering previously. Also, $29.9 \%$ of the participants reported that they have received accommodations since their first semester in higher education.

RQ2 Does academic accommodation use predict academic success for students with disabilities?

In predicting academic success (GPA), academic accommodation use was not a predictor of academic success and therefor the null hypothesis was not rejected. There was no significance in student academic success (GPA) and accommodation use. However, previous research shows that students with academic accommodations have a better chance of achieving academic success in higher education (Couzens et al., 2015). Although students with disabilities in higher education may have approved accommodations, this does not mean that they have guaranteed access to 
these approved accommodations (Massengale \& Vasquez, 2016). In this study, 63.1\% of the participants were not receiving academic accommodations while only $18 \%$ of the them answered they had used academic accommodations since their first semester. However, students may perceive accommodations as having academic value as $38.5 \%$ answered that accommodations influenced their academic progress.

Accommodations vary among institutions as well the definition of academic accommodation. In fact, institutions do not have to provide accommodations if they would incur costs that would be a financial or administrative burden (SDoE, 2011). Additionally, students with disabilities must personally notify faculty members of their accommodations because FERPA prohibits the campus office of disability from doing this. Failure to do this may mean that an accommodation is not honored because the faculty member was unaware of the student's needs and legal entitlements. Other findings included professors addressing less than half $(46.7 \%)$ of the participants' accommodation needs. One reason for this finding may be that faculty are uncertain as to the expectations (Gibbons et al., 2015). Some faculty will implement one or two accommodations, while others are unwilling to expand their knowledge or learn new methodologies or innovative technologies to support their students (Becker \& Palladino, 2016).

RQ3 Does the use of social support predict academic success for students with disabilities?

In predicting academic success (GPA), there was no significance in student academic success (GPA) and use of social support systems. The null hypothesis was not rejected. Results in this study showed that $43.6 \%$ of the participants agreed they had support within the community. By utilizing support systems, students with disabilities have a better chance of achieving academic success (Jairam \& Kahl, 2012). Jairam and Kahl (2012) argued that social and institutional support networks are positive and needed to help students be successful. These support networks help alleviate stress, reduce physical and psychological problems, and lower mortality rates. Stress can lead to illness and destructive behaviors such as drug and alcohol consumption, poor diet, and lack of exercise. Types of support systems include emotional, practical, and professional support (Jairam \& Kahl, 2012). This study found that $70.5 \%$ of participants go to their friends for help with school, $57.4 \%$ go their family for help, and $54.7 \%$ have joined or formed support groups with students in their classes.

RQ4 Does the use of institutional support predict academic success for students with disabilities?

In predicting academic success, institutional support system use failed to reject the null hypothesis. There was no significance in student academic success (GPA) and use of institutional support systems. In addition, most of the participants went to their faculty members for help with problems in the class (77.7\%). Forty-one-point eight percent of participants stated that they have sought academic support from the office of disabilities at some point in their college career while only $30.4 \%$ agree that their academic accommodation needs were being met through the disability office and a small percentage $(22.2 \%)$ mentioned that they go to the office of disabilities for help with their school problems.

In support of these findings, studies show that students are not utilizing the office of disability on their campuses (Lechtenberger et al., 2012). Also, only a third of the participants utilized the counseling center (33.6\%) as a place to go for help with their problems and less than half of the participants (41\%) go to their academic advisor with their school problems. Research shows that although students value counseling services, they are typically underutilized (Eisenburg, Hunt, \& Speer, 2012). Previous research explains students do not seek out professional campus counseling services include desire for privacy, fear of being found out, and personal beliefs about the stigma of receiving treatment (Marsh \& Wilcoxon, 2016) which can compound with stigma around having a disability (citation) and may influence non-use of support services.

\subsection{Implications for Practice}

The results of this study provided data to be used for university administrators, disability offices, lawmakers, faculty and staff, and any other individuals or groups that make decisions for students with disabilities in higher education. This research did not indicate any predictors of academic success when controlling for student disability registration, accommodation use, institutional support, and/or social support.

In addition, the results from this study led to several implications for future research. In the future, researchers may want to specifically target multiple higher education institutions in a certain geographical area and survey all the students on campus. Researchers may want to use only one social media outlet to reach participants as opposed to multiple. By including self-identification about type of disability (physical, emotional, learning), future research may study if one disability is impacted by the independent variables more than another. By categorizing the different types of disabilities, future researchers may focus on one group or compare them all. 
Future studies should investigate if student demographics impact academic success in higher education. This includes determining if academic success is predicted by registration, accommodation use, social support and institutional support when looking at specific demographic groups i.e. gender, ethnicity, year in college, etc. Each area of this research could be studied independently quantitatively and qualitatively. A qualitative study may provide data as to how students feel and what services really help them. Data collected in a qualitative study could help create a timeline as to the students' experiences with their services in higher education.

The findings of this research indicated that disability office registration did not predict academic success in students with disabilities in higher education. University and system administrators should seek out ways to educate students with disabilities in higher education on the processes and need for registering themselves with the office of disabilities. This must go beyond general flyers or disclaimers on the university webpage. By being a presence at recruitment and registration, as well as at campus socials, students with disabilities can get to know the processes and need for self-identification.

Whether it is because students with disabilities are not receiving them due to lack of registration, a misdiagnosis of accommodation needs, the lack of faculty knowledge, unwillingness to implement accommodation use, or a combination of all or none, the findings indicated accommodation use does not predict academic success. University and system administrators should create professional development programming focused on the needs of students with disabilities a priority and mandatory for all faculty. In addition to the needs of students with disabilities, university administrators must educate faculty and staff on the processes for implementing accommodations in the classroom. University stakeholders and system administrators must make a comprehensive list of accommodations used in higher education and create a thorough definition as to what accommodations look like in their system.

The results of this research found that social support systems did not predict academic success in students with disabilities in higher education. Although students with disabilities turn to their peers for help, only a little over half attended study groups. Additional research should include identifying why students are not utilizing social support systems like study groups. Organized student lead study groups are needed to increase student learning. Although students reached out to their family for help with school, often family members are not equipped to help the student with their academic work. Study tips training for family members could help them prepare for students' questions in the future.

In this study, institutional support did not predict academic success in students with disabilities in higher education. Specifically, additional research should include studies that specifically look at university and institutional administration personnel and their strategic action plans for meeting the needs of students with disabilities in higher education. The findings support the need for additional support from higher education institutions. In addition, system wide forums should be held in order for reflections and recommendations.

\subsection{Limitations}

There are several limitations to the current study. Students in this study volunteered for this survey which could have affected the results. Those students that have negative experiences with their office of disabilities may have been more inclined to complete this survey than those that are content with their experiences. Participants knew that there was no monetary reward for taking this survey and this may have affected the number of students that participated.

Other limitations include the measures that were used in the study. One hundred and eighty-two participants identified as having a disability that affects their school work, but only 122 completed the survey. The survey was presented as only taking 10-15 minutes, but some may have taken longer to complete the survey and got discouraged and quit. Also, the survey may have been confusing if the participant did not know what accommodations were. If the definition of accommodation would have been presented, this may have led to a higher completion rate.

Also, this survey did not ask the participants to identify their specific disability. For example, students that have a learning, physical, or emotional disability could have taken the survey regardless of disability.

This study focused on a small number of variables that specifically affect students with disabilities. Other variables may have contributed to the success of the students in the current research study, such as the frequency of accommodation use, the level of education and college experiences of their family members, the social and economic resources of their families, and their post-graduation education and career goals. It was not practical to control for these factors given the research design of the current study. Again, it opens up critical new areas for future research on the academic success of students with disability in higher education. 


\subsection{Contributions to the Literature}

The findings of this quantitative research suggest that although a student registers with the office of disabilities, it does not mean they are receiving adequate services. In the same way, although a student with a disability is registered with the office of disabilities and receives accommodations, accommodation use is not a significant predictor of student academic success. This suggests that the current method of determining a student's needed accommodations and the actual implementation of these accommodations may not be the best solution. When considering the institutional services provided for students in higher education, the research suggests that these services may not be adequate for their needs. Even though students may have a strong social support system, it does not significantly impact their academic success and therefore suggests that students with disabilities must seek out other support systems.

\subsection{Contributions to Practice}

The results of the study provided data to be used by system and university administrators, university stakeholders, faculty, staff, and lawmakers. Registration, accommodation use, institutional and social support systems did not indicate significant differences in the academic success of students with disabilities. With none of the independent variables predicting academic success in students with disabilities, this research suggests that higher education institutions are not meeting the needs of students with disabilities and additional research needs to be conducted to add to the body of knowledge.

\subsection{Recommendations for Future Research}

The results from this research confirm academic accommodations, registration with the office of disabilities, social support use, and institutional support use did not predict academic success. At a time when there are more students with disabilities in higher education than ever before in history, the need for awareness and support systems is imperative. Higher education institutions must research the most effective ways to reach their students and educate their faculty and staff to improve their institutional processes with students with disabilities in higher education.

This study sought to examine if registration with the office of disabilities, academic accommodation use, social support services, or institutional support services predicted academic success. The data analyzed in this study did not predict academic success. There are several recommendations for future research. The definition of reasonable accommodations in higher education must be clarified. Reasonable accommodations are modifications or adjustments to the tasks, environment or to the way things are usually done that enable individuals with disabilities to have an equal opportunity to participate in an academic program or a job (U.S. Department of Education, 2007). By correctly defining this, future research can examine the effects of a common definition on the academic success of students with disabilities.

In addition, by implementing and mandating faculty attendance at students with special needs centered professional developments, future research can examine the effect on academic success. The more awareness faculty and administrators have about students with disabilities, the more likely the student is to stay and the more successful the student can be (Walker, 2016). Next, universities do not have a cohesive organizational setup for the office of disabilities. By analyzing the different organizational setups, future research can compare and contrast the effectiveness of different disability office structures.

\subsection{Summary}

Due to the pressure on institutions of higher education to increase rates of retention and on-time graduation, research on how to support student success is multiplying exponentially. This has had a positive effect on research focusing on students with disabilities, which is also being conducted at an accelerated rate (Shallish, 2015). This research study provided quantitative data to determine if student support system usage predicts student academic success. It explored the importance of registering with the campus office of disability and it revealed if academic accommodation use predicts student academic success. Finally, this study added to the existing literature on the impact of institutional and social support systems.

The quantitative design for this study was a non-experimental research study which examined if academic success in students with disabilities was affected by a student's registration with the disability office, use of accommodations, use of institutional support systems and interaction with a social support system. The results of this study concluded that none of the independent variables were a predicter for academic success. This was supported through previous research from Howe (2013) in which accommodation use and social support use did not predict academic success. In addition, the findings of this research were also supported be previous research (Coetzer, 2009; Egan \& Giuliano, 2009; McCleary-Jones, 2008). 
The results of this study differed from previous research in such that none of the independent variables predicted academic success. In addition, due to the fact that there was a fourth category identified, which was composed of questions found in the previous research's social support category, none of the prior research was supported by this research. These results can be used to increase knowledge regarding students with disabilities and their success in higher education. The results will assist college and university administrators, lawmakers, and stakeholders, as well as staff in disability service offices in tracking the success of registration and accommodation use for students with disabilities. It can help university administration in better understanding the benefits of institutional support services. and encourage faculty involvement in implementing accommodations and helping students see the benefit of student registration with the campus office of disabilities.

\section{References}

American College Health Association (ACHA). (2013). National college health assessment II: Fall 2002 reference group executive summary. Hanover, MD: American College Health Association. Retrieved from http://www.acha-ncha.org/docs/acha-ncha-ii_referencegroup_executivesummary_fall2012.pdf

Americans with Disabilities Act (ADA) of 1988. 104 Stat. 327. Retrieved from https://www.govtrack.us/congress/bills/100/s2345

Arco-Tirado, J. L., Fernandez-Martin, F. D., \& Fernandez-Balboa, J. (2011). The impact of a peer-tutoring program on quality standards in higher education. Higher Education, 62(6), 773-778. https://doi.org/10.1007/s10734-011-9419-x

Becker, S., \& Palladino, J. (2016). Assessing faculty perspectives about teaching and working with students with disabilities. Journal of Post-secondary Education \& Disability, 29(1), 65-82.

Bishop, J. B. (2010). The counseling center: An undervalued resource in recruitment, retention, and risk management. Journal of College Student Psychotherapy, 24, 248-260. https://doi.org/10.1080/87568225.2010.509219

Couzens, D., Poed, S., Kataoka, M., Brandon, A., Hartley, J., \& Keen, D. (2015). Support for students with hidden disabilities in universities: A case study. International Journal of Disability, Development and Education, 62(1), 24-41. https://doi.org/10.1080/1034912X.2014.984592

Drago, A., Rheinheimer, D. C., \& Detweiler, T. N. (2018). Effects of locus of control, academic self-efficacy, and tutoring on academic performance. Journal of College Student Retention: Research, Theory \& Practice, 19(4), 433-451. https://doi.org/10.1177/1521025116645602

Eisenberg, D., Speer, N., \& Hunt, J. B. (2012). Attitudes and beliefs about treatment among college students with untreated mental health problems. Psychiatric Services, 63, 711-713. https://doi.org/10.1176/appi.ps.201100250

Gibbons, M. M., Cihak, D. D., Mynatt, B. B., \& Wilhoit, B. B. (2015). Faculty and student attitudes toward post-secondary education for students with intellectual disabilities and autism. Journal of Post-secondary Education \& Disability, 28(2), 149-162.

Gliem, J. \& Gliem, R. (2003). Calculating, interpreting, and reporting Cronbach's alpha reliability coefficient for Likert-type scales. In 2003 Midwest Research to Practice Conference, 82-88.

Howe, S. M. (2013). Academic accommodations, social supports, and academic self-efficacy: Predictors of academic success for post-secondary students with disabilities (Doctoral dissertation). Retrieved from ProQuest. (163)

Jairam, D., \& Kahl, D. (2012). Navigating the doctoral experience: The role of social support in successful degree completion. International Journal of Doctoral Studies, 7, 311-329. https://doi.org/10.28945/1700

Kayhan, N., Sen, M., \& Akcamete, G. (2015). Opinions of university students with disabilities on current regulations and adaptations at higher education institutions. Procedia - Social and Behavioral Sciences, 197(20), 635-639. https://doi.org/10.1016/j.sbspro.2015.07.050

Lechtenberger, D., Brak, L. B., Sokolosky, S., \& McCrary, D. (2012). Using wraparound to support students with developmental disabilities in higher education. College Student Journal, 46(4), 856-866.

Liddicoat, A. J., \& Taylor-Leech, K. (2015). Multilingual education: The role of language ideologies and attitudes. Current Issues in Language Planning, 16(1), 1-7. https://doi.org/10.1080/14664208.2015.995753 
Lombardi, A. R., Murray, C., \& Gerdes, H. (2012). Academic performance of first-generation college students with disabilities. Journal of College Student Development, $53(6), \quad 811-\quad 826$. https://doi.org/10.1080/14664208.2015.995753

Marsh, C. N., \& Wilcoxon, S. A. (2015). Underutilization of mental health services among college students: An examination of system-related barriers. Journal of College Student Psychotherapy, 29(3), 227-243. https://doi.org/10.1080/87568225.2015.1045783

Massengale, L. L., \& Vasquez, E. E. (2016). Assessing accessibility: How accessible are online courses for students with disabilities? Journal of The Scholarship of Teaching \& Learning, 16(1), 69-79. https://doi.org/10.14434/josotl.v16i1.19101

McKelvey, R. D., \& Zavoina, W. (1975). A statistical model for the analysis of ordinal level dependent variables. Journal of Mathematical Sociology, 4(1), 103. https://doi.org/10.1080/0022250X.1975.9989847

Michael, R. F. (2016). The Perceived success of tutoring students with learning disabilities: relations to tutee and tutoring variables. Journal of Post-Secondary Education \& Disability, 29(4), 349-361.

Murray, C., Lombardi, A., \& Wren, C. T. (2011). The effects of disability-focused training on the attitudes and perceptions of university staff. Remedial and Special Education, 32(4), 290-300. https://doi.org/10.1177/0741932510362188

National Alliance on Mental Illness (NAMI). (2012). College students speak: A survey report on mental health. Retrieved

from https://www.nami.org/About-NAMI/Publications-Reports/Survey-Reports/College-Students-Speak_A-SurveyReport-on-Mental-H.pdf

Pugatch, T., \& Wilson, N. (2018). Nudging study habits: A field experiment on peer tutoring in higher education. Economics of Education Review, 62,151-161. https://doi.org/10.1016/j.econedurev.2017.11.003

Sachs, D., \& Schreuer, N. (2011). Inclusion of students with disabilities in higher education: Performance and participation in student's experiences. Disability Studies Quarterly, 31(2), 13. https://doi.org/10.18061/dsq.v31i2.1593

Shallish, L. (2015). "Just how much diversity will the law permit?": The Americans with disabilities act, diversity, and disability in higher education. Disability Studies Quarterly, 35(3), 8. https://doi.org/10.18061/dsq.v35i3.4942

Spector, P. (1992). Summated rating scale construction. Thousand Oaks, CA: Sage. https://doi.org/10.4135/9781412986038

Thurstone, L. L. (1947). Multiple factor analysis. Chicago, IL: University of Chicago Press.

United States Department of Education (USDoE). (2011). Students with disabilities preparing for post-secondary education. Retrieved from https://www2.ed.gov/about/offices/list/ocr/transition.html

United States Department of Education (USDoE). (2015). Compilation of the social security laws: including the Social Security Act, as amended, and related enactments through. Retrieved from https://archive.org/details/compilationofsoc00unit_6

Walker, L. (2016). Impact of academic support centers on students with disabilities in post-secondary institutions. Learning Assistance Review, 21(1), 82- 92. 


\section{APPENDIX A \\ ACADEMIC ACCOMODATIONS SURVEY}

1. You must be 18 years or older to take this survey. Are you the legal age of 18 years or older?

2. Gender
Male
Female

3. Which race/ethnicity best describes you? (Please choose only one.)

American Indian or Alaskan Native

Asian / Pacific Islander

Black or African American

Hispanic

White / Caucasian

Multiple ethnicity / Other (please specify)

4. Do you have a disability/impairment that affects your school work?

5. What year in school are you?

6 . What is your major?

7. What is your age?

8. Are you a part time or full-time student?

9. Are you currently on academic probation?

10. Have you ever been on academic probation?

11. Have you ever been registered with the Office of Disabilities here on campus?

12. What is your GPA?

13. Are you currently registered with the Office of Disabilities here on campus?

14. Have you used academic accommodations since your first semester of college?

15. At what age were you at the initial onset of your disability?

16. How many semesters in total have you used academic accommodations (Attending classes in the summer counts as one semester)?

17. Are you currently receiving academic accommodations?

18. Please indicate your level of agreement with each statement. 


\begin{tabular}{|c|c|c|c|c|c|}
\hline & Strongly Agree & Agree & $\begin{array}{l}\text { Neither agree nor } \\
\text { disagree }\end{array}$ & Disagree & Strongly Disagree \\
\hline $\begin{array}{l}\text { My Requested } \\
\text { accommodation(s) } \\
\text { have been } \\
\text { addressed by my } \\
\text { professors }\end{array}$ & $\begin{array}{l}\text { My Requested } \\
\text { accommodation(s) } \\
\text { have been } \\
\text { addressed by my } \\
\text { professors Strongly } \\
\text { Agree }\end{array}$ & $\begin{array}{l}\text { My Requested } \\
\text { accommodation(s) have } \\
\text { been addressed by my } \\
\text { professors Agree }\end{array}$ & $\begin{array}{l}\text { My Requested } \\
\text { accommodation(s) have } \\
\text { been addressed by my } \\
\text { professors Neither agree } \\
\text { nor disagree }\end{array}$ & $\begin{array}{l}\text { My Requested } \\
\text { accommodation(s) have } \\
\text { been addressed by my } \\
\text { professors Disagree }\end{array}$ & $\begin{array}{l}\text { My Requested } \\
\text { accommodation(s) have } \\
\text { been addressed by my } \\
\text { professors Strongly } \\
\text { Disagree }\end{array}$ \\
\hline $\begin{array}{l}\text { I go to my } \\
\text { professor when I } \\
\text { have a problem in } \\
\text { class. }\end{array}$ & $\begin{array}{l}\text { I go to my professor } \\
\text { when I have a } \\
\text { problem in } \\
\text { class. Strongly } \\
\text { Agree }\end{array}$ & $\begin{array}{l}\text { I go to my professor } \\
\text { when I have a problem } \\
\text { in class. Agree }\end{array}$ & $\begin{array}{l}\text { I go to my professor when } \\
\text { I have a problem in } \\
\text { class. Neither agree nor } \\
\text { disagree }\end{array}$ & $\begin{array}{l}\text { I go to my professor } \\
\text { when I have a problem in } \\
\text { class. Disagree }\end{array}$ & $\begin{array}{l}\text { I go to my professor when } \\
\text { I have a problem in } \\
\text { class. Strongly Disagree }\end{array}$ \\
\hline $\begin{array}{l}\text { I have sought } \\
\text { academic support } \\
\text { from the disability } \\
\text { office }\end{array}$ & $\begin{array}{l}\text { I have sought } \\
\text { academic support } \\
\text { from the disability } \\
\text { office Strongly } \\
\text { Agree }\end{array}$ & $\begin{array}{l}\text { I have sought academic } \\
\text { support from the } \\
\text { disability office Agree }\end{array}$ & $\begin{array}{l}\text { I have sought academic } \\
\text { support from the } \\
\text { disability office Neither } \\
\text { agree nor disagree }\end{array}$ & $\begin{array}{l}\text { I have sought academic } \\
\text { support from the } \\
\text { disability } \\
\text { office Disagree }\end{array}$ & $\begin{array}{l}\text { I have sought academic } \\
\text { support from the } \\
\text { disability office Strongly } \\
\text { Disagree }\end{array}$ \\
\hline $\begin{array}{l}\text { I go to the } \\
\text { disability office for } \\
\text { help with school } \\
\text { problems }\end{array}$ & $\begin{array}{l}\text { I go to the disability } \\
\text { office for help with } \\
\text { school } \\
\text { problems Strongly } \\
\text { Agree }\end{array}$ & $\begin{array}{l}\text { I go to the disability } \\
\text { office for help with } \\
\text { school problems Agree }\end{array}$ & $\begin{array}{l}\text { I go to the disability } \\
\text { office for help with } \\
\text { school problems Neither } \\
\text { agree nor disagree }\end{array}$ & $\begin{array}{l}\text { I go to the disability } \\
\text { office for help with } \\
\text { school } \\
\text { problems Disagree }\end{array}$ & $\begin{array}{l}\text { I go to the disability } \\
\text { office for help with } \\
\text { school problems Strongly } \\
\text { Disagree }\end{array}$ \\
\hline $\begin{array}{l}\text { I go to the } \\
\text { counseling center } \\
\text { for help with } \\
\text { problems }\end{array}$ & $\begin{array}{l}\text { I go to the } \\
\text { counseling center } \\
\text { for help with } \\
\text { problems Strongly } \\
\text { Agree }\end{array}$ & $\begin{array}{l}\text { I go to the counseling } \\
\text { center for help with } \\
\text { problems Agree }\end{array}$ & $\begin{array}{l}\text { I go to the counseling } \\
\text { center for help with } \\
\text { problems Neither agree } \\
\text { nor disagree }\end{array}$ & $\begin{array}{l}\text { I go to the counseling } \\
\text { center for help with } \\
\text { problems Disagree }\end{array}$ & $\begin{array}{l}\text { I go to the counseling } \\
\text { center for help with } \\
\text { problems Strongly } \\
\text { Disagree }\end{array}$ \\
\hline $\begin{array}{l}\text { I have support } \\
\text { within the } \\
\text { community that } \\
\text { help me with my } \\
\text { school problems }\end{array}$ & $\begin{array}{l}\text { I have support } \\
\text { within the } \\
\text { community that } \\
\text { help me with my } \\
\text { school } \\
\text { problems Strongly } \\
\text { Agree }\end{array}$ & $\begin{array}{l}\text { I have support within } \\
\text { the community that } \\
\text { help me with my school } \\
\text { problems Agree }\end{array}$ & $\begin{array}{l}\text { I have support within the } \\
\text { community that help me } \\
\text { with my school } \\
\text { problems Neither agree } \\
\text { nor disagree }\end{array}$ & $\begin{array}{l}\text { I have support within the } \\
\text { community that help me } \\
\text { with my school } \\
\text { problems Disagree }\end{array}$ & $\begin{array}{l}\text { I have support within the } \\
\text { community that help me } \\
\text { with my school } \\
\text { problems Strongly } \\
\text { Disagree }\end{array}$ \\
\hline $\begin{array}{l}\text { I go to my friends } \\
\text { for help with } \\
\text { school problems }\end{array}$ & $\begin{array}{l}\text { I go to my friends } \\
\text { for help with school } \\
\text { problems Strongly } \\
\text { Agree }\end{array}$ & $\begin{array}{l}\text { I go to my friends for } \\
\text { help with school } \\
\text { problems Agree }\end{array}$ & $\begin{array}{l}\text { I go to my friends for help } \\
\text { with school } \\
\text { problems Neither agree } \\
\text { nor disagree }\end{array}$ & $\begin{array}{l}\text { I go to my friends for } \\
\text { help with school } \\
\text { problems Disagree }\end{array}$ & $\begin{array}{l}\text { I go to my friends for help } \\
\text { with school } \\
\text { problems Strongly } \\
\text { Disagree }\end{array}$ \\
\hline $\begin{array}{l}\text { I go to my family } \\
\text { members for help } \\
\text { with school } \\
\text { problems }\end{array}$ & $\begin{array}{l}\text { I go to my family } \\
\text { members for help } \\
\text { with school } \\
\text { problems Strongly } \\
\text { Agree }\end{array}$ & $\begin{array}{l}\text { I go to my family } \\
\text { members for help with } \\
\text { school problems Agree }\end{array}$ & $\begin{array}{l}\text { I go to my family } \\
\text { members for help with } \\
\text { school problems Neither } \\
\text { agree nor disagree }\end{array}$ & $\begin{array}{l}\text { I go to my family } \\
\text { members for help with } \\
\text { school } \\
\text { problems Disagree }\end{array}$ & $\begin{array}{l}\text { I go to my family } \\
\text { members for help with } \\
\text { school problems Strongly } \\
\text { Disagree }\end{array}$ \\
\hline $\begin{array}{l}\text { I rely on myself to } \\
\text { solve my own } \\
\text { problems }\end{array}$ & $\begin{array}{l}\text { I rely on myself to } \\
\text { solve my own } \\
\text { problems Strongly } \\
\text { Agree }\end{array}$ & $\begin{array}{l}\text { I rely on myself to solve } \\
\text { my own } \\
\text { problems Agree }\end{array}$ & $\begin{array}{l}\text { I rely on myself to solve } \\
\text { my own } \\
\text { problems Neither agree } \\
\text { nor disagree }\end{array}$ & $\begin{array}{l}\text { I rely on myself to solve } \\
\text { my own } \\
\text { problems Disagree }\end{array}$ & $\begin{array}{l}\text { I rely on myself to solve } \\
\text { my own } \\
\text { problems Strongly } \\
\text { Disagree }\end{array}$ \\
\hline
\end{tabular}




\begin{tabular}{|c|c|c|c|c|c|}
\hline & Strongly Agree & Agree & $\begin{array}{l}\text { Neither agree nor } \\
\text { disagree }\end{array}$ & Disagree & Strongly Disagree \\
\hline $\begin{array}{l}\text { I do not want to be } \\
\text { labeled as a student } \\
\text { with a disability }\end{array}$ & $\begin{array}{l}\text { I do not want to be } \\
\text { labeled as a student } \\
\text { with a } \\
\text { disability Strongly } \\
\text { Agree }\end{array}$ & $\begin{array}{l}\text { I do not want to be } \\
\text { labeled as a student } \\
\text { with a disability Agree }\end{array}$ & $\begin{array}{l}\text { I do not want to be } \\
\text { labeled as a student with a } \\
\text { disability Neither agree } \\
\text { nor disagree }\end{array}$ & $\begin{array}{l}\text { I do not want to be } \\
\text { labeled as a student with } \\
\text { a disability Disagree }\end{array}$ & $\begin{array}{l}\text { I do not want to be } \\
\text { labeled as a student with a } \\
\text { disability Strongly } \\
\text { Disagree }\end{array}$ \\
\hline $\begin{array}{l}\text { I have joined or } \\
\text { formed study } \\
\text { groups with } \\
\text { students in my } \\
\text { classes }\end{array}$ & $\begin{array}{l}\text { I have joined or } \\
\text { formed study } \\
\text { groups with } \\
\text { students in my } \\
\text { classes Strongly } \\
\text { Agree }\end{array}$ & $\begin{array}{l}\text { I have joined or formed } \\
\text { study groups with } \\
\text { students in my } \\
\text { classes Agree }\end{array}$ & $\begin{array}{l}\text { I have joined or formed } \\
\text { study groups with } \\
\text { students in my } \\
\text { classes Neither agree nor } \\
\text { disagree }\end{array}$ & $\begin{array}{l}\text { I have joined or formed } \\
\text { study groups with } \\
\text { students in my } \\
\text { classes Disagree }\end{array}$ & $\begin{array}{l}\text { I have joined or formed } \\
\text { study groups with } \\
\text { students in my } \\
\text { classes Strongly Disagree }\end{array}$ \\
\hline $\begin{array}{l}\text { My academic } \\
\text { needs are being } \\
\text { met though } \\
\text { accommodations } \\
\text { from the disability } \\
\text { office }\end{array}$ & $\begin{array}{l}\text { My academic needs } \\
\text { are being met } \\
\text { though } \\
\text { accommodations } \\
\text { from the disability } \\
\text { office Strongly } \\
\text { Agree }\end{array}$ & $\begin{array}{l}\text { My academic needs are } \\
\text { being met though } \\
\text { accommodations from } \\
\text { the disability } \\
\text { office Agree }\end{array}$ & $\begin{array}{l}\text { My academic needs are } \\
\text { being met though } \\
\text { accommodations from } \\
\text { the disability } \\
\text { office Neither agree nor } \\
\text { disagree }\end{array}$ & $\begin{array}{l}\text { My academic needs are } \\
\text { being met though } \\
\text { accommodations from } \\
\text { the disability } \\
\text { office Disagree }\end{array}$ & $\begin{array}{l}\text { My academic needs are } \\
\text { being met though } \\
\text { accommodations from } \\
\text { the disability } \\
\text { office Strongly Disagree }\end{array}$ \\
\hline $\begin{array}{l}\text { I go to my } \\
\text { academic adviser } \\
\text { for help with } \\
\text { school problems }\end{array}$ & $\begin{array}{l}\text { I go to my academic } \\
\text { adviser for help } \\
\text { with school } \\
\text { problems Strongly } \\
\text { Agree }\end{array}$ & $\begin{array}{l}\text { I go to my academic } \\
\text { adviser for help with } \\
\text { school problems Agree }\end{array}$ & $\begin{array}{l}\text { I go to my academic } \\
\text { adviser for help with } \\
\text { school problems Neither } \\
\text { agree nor disagree }\end{array}$ & $\begin{array}{l}\text { I go to my academic } \\
\text { adviser for help with } \\
\text { school } \\
\text { problems Disagree }\end{array}$ & $\begin{array}{l}\text { I go to my academic } \\
\text { adviser for help with } \\
\text { school problems Strongly } \\
\text { Disagree }\end{array}$ \\
\hline $\begin{array}{l}\text { Academic } \\
\text { Accommodations } \\
\text { have influenced } \\
\text { my academic } \\
\text { progress }\end{array}$ & $\begin{array}{l}\text { Academic } \\
\text { Accommodations } \\
\text { have influenced my } \\
\text { academic } \\
\text { progress Strongly } \\
\text { Agree }\end{array}$ & $\begin{array}{l}\text { Academic } \\
\text { Accommodations have } \\
\text { influenced my } \\
\text { academic } \\
\text { progress Agree }\end{array}$ & $\begin{array}{l}\text { Academic } \\
\text { Accommodations have } \\
\text { influenced my academic } \\
\text { progress Neither agree } \\
\text { nor disagree }\end{array}$ & $\begin{array}{l}\text { Academic } \\
\text { Accommodations have } \\
\text { influenced my academic } \\
\text { progress Disagree }\end{array}$ & $\begin{array}{l}\text { Academic } \\
\text { Accommodations have } \\
\text { influenced my academic } \\
\text { progress Strongly } \\
\text { Disagree }\end{array}$ \\
\hline
\end{tabular}

